\title{
MAYER-ROKITANSKY-KÜSTER-HAUSER SYNDOME AND LAPAROSCOPIC ASSISTED CREATION OF NEOVAGINA (MODIFIED VECCHIETTI)
}

\author{
Fatih SENDAG, Ali AKDEMIR, Levent AKMAN, Mehmet Kemal OZTEKIN
}

Department of Obstetrics and Gynecology, Ege University, Faculty of Medicine, Izmir, Turkey

\begin{abstract}
SUMMARY
Objective: To report the post operative 6 month results of tree patients with Mayer-Rokitansky-Küster-Hauser (MRKH) syndrome who underwent laparoscopic assisted creation of neovagina (Modified Vecchietti) by using "Neovagina Set" for the first time in our clinic.

Design: Prospective evaluation.

Setting: University hospital

Patients: Three patients with MHRK syndrome.

Interventions: Laparoscopic assisted creation of neovagina (Modified Vecchietti) by using neovagina set.

Main outcome measures: Duration of surgery, duration of hospitalisation, intraoperative and post operative complications, post operative respect and maintenance, anatomical and functional results, sexual satisfaction, vaginal epithelization.

Results: Operation times were 60, 55, 50 minutes, respectively. Hospitalisation was 7 days for three patients. Anatomical vaginal lenght was 7,8,9.5 cm, respectively and vaginal epithelization was completed at 24, 20, 24 months after surgery, respectively.

Conclusions: Laparoscopic modified Vecchietti technique with using "neovagina set", which was created and was standardized for this operation, to performe a neovagina should be kept in mind as one of the first step option for patients with MHRK syndrome.
\end{abstract}

Key words: laparoscopic creation of neovagina, Mayer-Rokitansky-Küster-Hauser syndrome, Neovagina set, Vecchietti procesure,

Journal of Turkish Society of Obstetrics and Gynecology, (J Turk Soc Obstet Gynecol), 2013; Vol: 10, Issue: 4, Pages: 260- 6

\section{MAYER-ROKITANSKY-KÜSTER-HAUSER SENDROMU VE LAPAROSKOPIK YARDIMLI NEOVAJINA OLUŞTURULMASI (MODIFIYYE VECCHIETTI)}

\section{ÖZET}

Objektif: Kliniğimizde "Neovagina Set" kullanarak ilk kez laparoskopik yardımlı neovagina oluşturulmuş MayerRokitansky-Küster-Hauser (MRKH) sendromlu 3 hastanın 6 aylık sonuçlarının değerlendirilmesi.

Planlama: Prospektif de ğerlendirme.

Ortam: Üniversite hastanesi

Hastalar: MHRK sendromu tanılı üç hasta.

Girişim: Neovajina set ile laparoskopik yardımlı neovagina (Modifiye Vecchietti) oluşturulması.

Değerlendirme Parametreleri: Operasyon zamani, per-post operatif komplikasyonlar, anatomik ve fonksiyonel vaginal uzunluk, postoperatif bakım ve takip, vaginal epitelizasyon ve cinsel ilişki memnuniyeti değerlendirilmiştir.

Sonuç: Operasyon süresi sırası ile 60, 55, 50 dakikadır. Hastanede kalış süresi üç hasta içinde 7 gündür. Operasyon

Address for Correspondence: Dr. Ali Akdemir. Ege Üniversitesi Tıp Fakültesi, Kadın Hastalıkları ve Doğum Anabilim Dalı, 35040 İzmir Phone: + 90 (505) 6748904

e-mail: ali.akdemir@ege.edu.tr

Received: 27 August 2012, revised: 18 December 2012, accepted: 09 January 2013, online publication: 10 January 2013 
sonrası anatomik vaginal uzunluk sırast ile 7, 8, $9.5 \mathrm{~cm}$ dir. Vajinal epitelizasyon strası ile 24, 20 ve 24. haftalarda

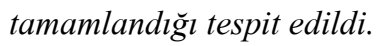

Yorum: Neovajina oluşturulması için laparoskopik modifiye Vecchietti tekniğinin bu amaç için oluşturulmuş ve standardize edilmiş "neovajina set" kullanılarak gerçekleştirilmesi MHRK sendromu olan hastalar için ilk tedavi seçenekleri arasında olduğu akılda tutulmalıdır.

Anahtar kelimeler: laparoskopik yeni vajen oluşturulmasl, Mayer-Rokitansky-Küster-Hauser sendromu, neovajina set, vecchietti prosedürü Türk Jinekoloji ve Obstetrik Derneği Dergisi, (J Turk Soc Obstet Gynecol), 2013; Cilt: 10, Sayl: 4, Sayfa: 260- 6

\section{INTRODUCTION}

Mayer - Rokitansky-Küstner-Hauser(MRKH) syndrom, is a rare congenital abnormality which is characterised by patients whom have variable müllerian duct abnormalities with vagina and uterine agenesia and normal seconder sexual characters with normal karyotype. Incidence is predicted as 1/4000-5000 viable female birth ${ }^{(1)}$. Patients have normal karyotype and normal external genitalia therefore they are usually diagnosed by primary amenorrhea in adolescence. Also additional urinary and skeletal system abnormalities can be found with this syndrom. Etiophatogenethic machanism is not clearly known, although it is known as the defect of müllerian tube's cohesion between 4 and 12 weeks of gestation ${ }^{(2)}$.

It is required to create a new vagina for the patients having this syndrom since they do not have any phsycological and physical handicap for having a normal sexual life ${ }^{(3,4)}$. There are lots of reports in the medical literature about operative techniques for this purpose. It is understood that both non-invasive techniques as applying serial dilatation, and invasive techniques as McIndoe, intestinal vaginoplasty, Vecchietti procedure, Davydov procedure, WhartonSheares-George procedure etc. are used to create a new vagina ${ }^{(3,5-8)}$. Although these operative technics have advantages and disadvantages, the common disadvantage of almost all of them is high morbidity. In medical literature, it is seen that, as in all the surgical fields, also in gynecology, less invasive surgery with laparascopic approach is getting popular. At this point of view it is understood that the operations for creating new vagina, are modified to be less invasive by laparascopic strategies .

One of the mentioned methods, in Vecchietti procedure; after dissection of rectovaginal space by abdominovaginal approach, neovagina is created stretching agenetic vagina internally and provides elongation ${ }^{(9)}$. In laparascopic modified Vecchietti procedure neovagina is created in the same way without dissection of rectovaginal space $(5,6)$. It is noticed in the historical course that various authors used different mechanisms and tools to stretch agenetic vagina in laparascopic Vecchietti operation. A special set named 'Neovagina Set'( Karl-Storz, Germany), which is developed and standardized for this operation, is used remarkably nowadays.

Our aim in this report is to announce our results in three patients of our first experience of creating neovagina with laparascopic assisted by using 'Neovagina Set' (modified Vecchietti) in the perspective of literature.

\section{MATERIAL AND METHOD}

In our clinic, we performed laparascopic assisted neovagina (Modified Vecchietti) with 'Neovagina Set' in three patients. The patients were evaluated preoperatively with full clinical examination, karyotype analysis, sonografic and magnetic resonance imaging. The results about operative technique (duration of operation, duration of hospitalisation, complication), function (anatomical and functional vaginal length, vaginal width, vaginal epithelialization), sexual life after operation (first time for intercourse, pain during intercourse, need of lubricant, satisfaction) are evaluated. The patients signed detailed informed consent form. 


\section{Surgical Technique}

A specially developed set including traction device, straight and curve string guide and vaginal molds in variable dimensions, which is developed for this operation, 'Neovagina set '(Karl-Storz ,Germany), is used (Figure 1).

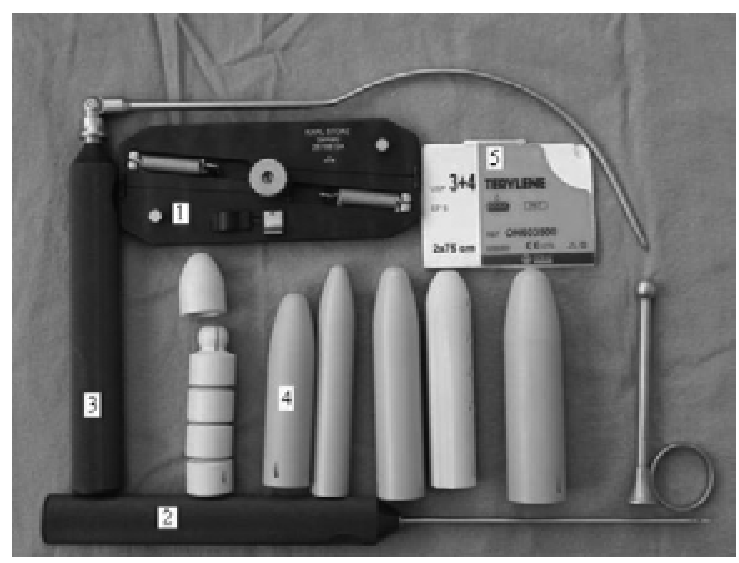

Figure 1: Neovagina Set, 1. Traction device, 2. Straight string guide, 3. Curved string guide, 4. Dilators with different diameters and sizes. 5. Traction string.

All three procedures were performed under endotracheal general anesthesia on dorsolithotomy position. Pelvic observation was made using a $10 \mathrm{~mm}$ umbilical trocar and a $5 \mathrm{~mm}$ suprapubic trocar after pneumoperitoneum was achieved using veress needle through umbilicus. Subsequently, perforation level for releasing of number four traction strings (Trylene, Serag-Weissner KG, Naila, Germany) into the abdomen through the top of the blind ending vagina was determined with laparoscopic and sistoscopic observation. The top of the blind-ending vagina was pushed into the abdomen, using bilateral index fingers, therefore providing a relaxation of the top of the blind-ending vagina. Rectum was pushed to posterior using the middle finger of one hand, and blind ending vagina was then perforated with slightly curved suture carrier with the guidance of the index finger, and then, traction strings were taken into the abdomen. During this procedure, rudimenter uterus was retracted laparoscopically using laparoscopic forceps cranioventrally to prevent bladder injury (Figure.2). The traction strings lying outside the vagina were attached to the vaginal mould $(3 \mathrm{~cm}$ in diameter and $3 \mathrm{~cm}$ in length) and prepared for traction. Subsequently the cranial margin of the traction device was placed at the inferior curve of umbilicus and the points for the traction strings to be taken out of the abdomen, was marked on the skin. Strongly curved ligature carriers were taken into the abdomen through these points and pushed forward to the top of the blind ending vagina (Figure 3 ). The bladder was filled with about $300 \mathrm{cc}$ saline to identify its margins and bladder injury was prevented via strongly curved ligature carrier during this procedure. The traction strings in the abdomen were attached to strongly curved ligature carrier and then taken out of the abdomen subperitoneally. Traction device was placed on the previously marked area and the strings were fixed to the traction device. Finally, blind ending vagina was stretched internally with the help of the screw on the traction device (Figure 3).

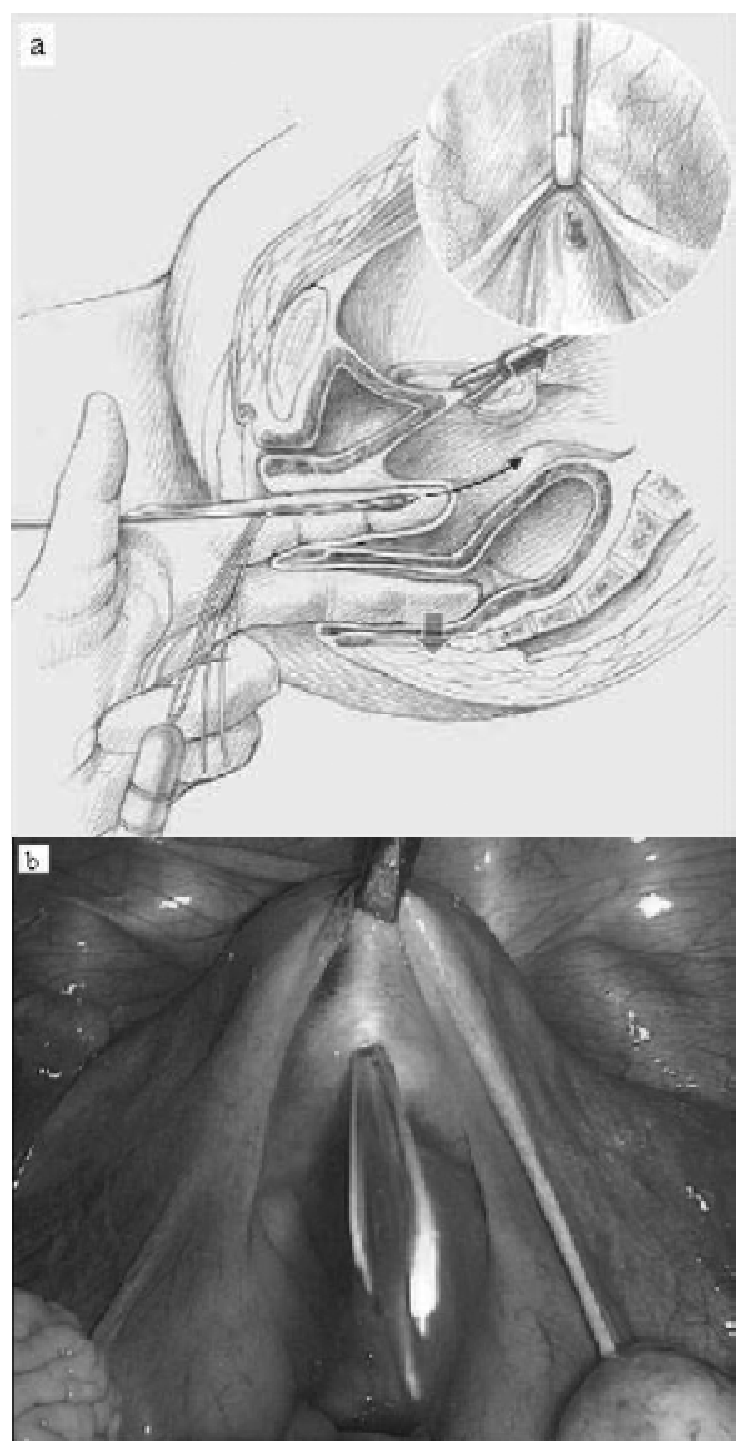

Figure 2: Perforation of the blind vaginal apex into the abdomen with the straight string guide. a. graphic illustration $b$. perioperative view. 


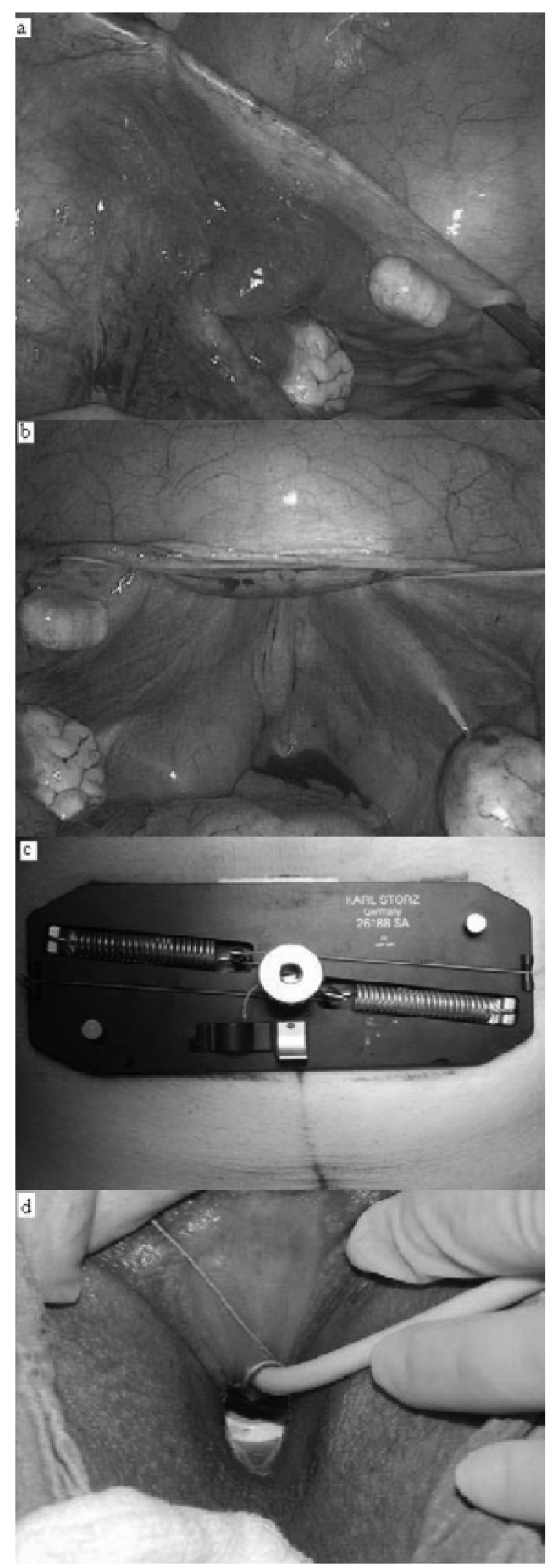

Figure 3: a. Subperitoneal tunnel formation using a curved string guide b. Pelvic view after strings bilaterally taken out of the subperitoneal tunnel c. Placing the traction device at the umblicus level and tying the string $d$. Perineal view after perioperative establishment of the traction device.
Elongation of the blind-ending vagina was achieved by strecthing the traction device daily for post operavite five days. Analgesia with an epidural catheter was provided to eliminate the pain resulted from the daily tractions. Although the mobilization of patients was restricted due to the traction device, foley urinary catheter remained for five days. Patients were given prophilactic antibiotics and low molecular weight heparin therapy for five days.

On the postoperative fifth day the traction strings were cut and traction device, traction strings and short vagina mould replaced in vagina were removed under intravenous sedation. At the same session, depth of vagina was identified and estrogene cream applied vagina moulds of appropriate size and length were placed and foley urinary catheters were removed. Patients were discharged at seventh postoperative day and told not to remove the vagina moulds they were given except during intercourse, toilet and bathroom usages (Patients allowed to intercourse one moth after the surgery). All the patients were followed once a week for a month, then once a month. Patients were informed that the vagina moulds that they were given, should be washed with soap every time and applied again after estrogen cream application. Patients were advised to apply vagina moulds appropriately to vagina several nights in a week until sixth month unless they had regular intercourse after postoperative third month.

\section{Results}

Ages of the patients were 24, 30 and 36. Neither of them had abdominal operation and had no other abnormality except vaginal agenesia. Results about operative technique, function and sexual life after operation are shown in order in table 1. No complications were encountered about the operative technique. Two patients had fewer up to $38.5 \mathrm{C}$ at post operative 48. hour and contunied for two days, one of the patients got urinary tract infection at first month after operation and medical treatment applied. While the traction device was installed on patients for five days post operative, patients analgesie was provided by an epidural catheter and had no complications about it. All three patients were discharged post operative seventh day. During post operative follow up, for evaluation of vaginal epithelialization; kolposcopic examination and Schiller test was applied. As epithelialization is considered to be completed 
subjectively then vaginal biopsy is performed for pathological confirmation (Figure 4).

Table I: Operative technic, anatomical and functional results, post operative sexual life results. Anatomical vaginal lenght is measured without pushing the vaginal apex into abdomen, functional vaginal lenght is measured while slighty pushing the vaginal apex into the abdomen. (* No sexual partners at the post operative 6th month).

\begin{tabular}{|c|c|c|c|}
\hline & Patient 1 & Patient 2 & Patient 3 \\
\hline Duration of surgery (min) & 60 & 55 & 50 \\
\hline Preoperative vaginal lenght $(\mathrm{cm})$ & 1.5 & 2 & 2.5 \\
\hline \multicolumn{4}{|l|}{ Anatomical vaginal lenght (cm) } \\
\hline 3th month & 7.5 & 8.5 & 10 \\
\hline 6th month & 7.0 & 8.0 & 9.5 \\
\hline \multicolumn{4}{|l|}{ FFunctional vaginal lenght $(\mathrm{cm})$} \\
\hline 3 th month & 9.0 & 9.5 & 11.5 \\
\hline 6th month & 8.5 & 9.0 & 11.5 \\
\hline \multicolumn{4}{|l|}{ Vaginal width $(\mathrm{cm})$} \\
\hline 3th month & 2 & 2 & 2.5 \\
\hline 6th month & 2 & 2 & 2.5 \\
\hline First sexual intercourse (week) & 6 & 5 & $*$ \\
\hline Need of lubricant & No & No & $*$ \\
\hline Pain during sexual intercourse & No & No & $*$ \\
\hline $\begin{array}{l}\text { Vaginal epithelialization time } \\
\text { (week) }\end{array}$ & 24 & 20 & 24 \\
\hline
\end{tabular}
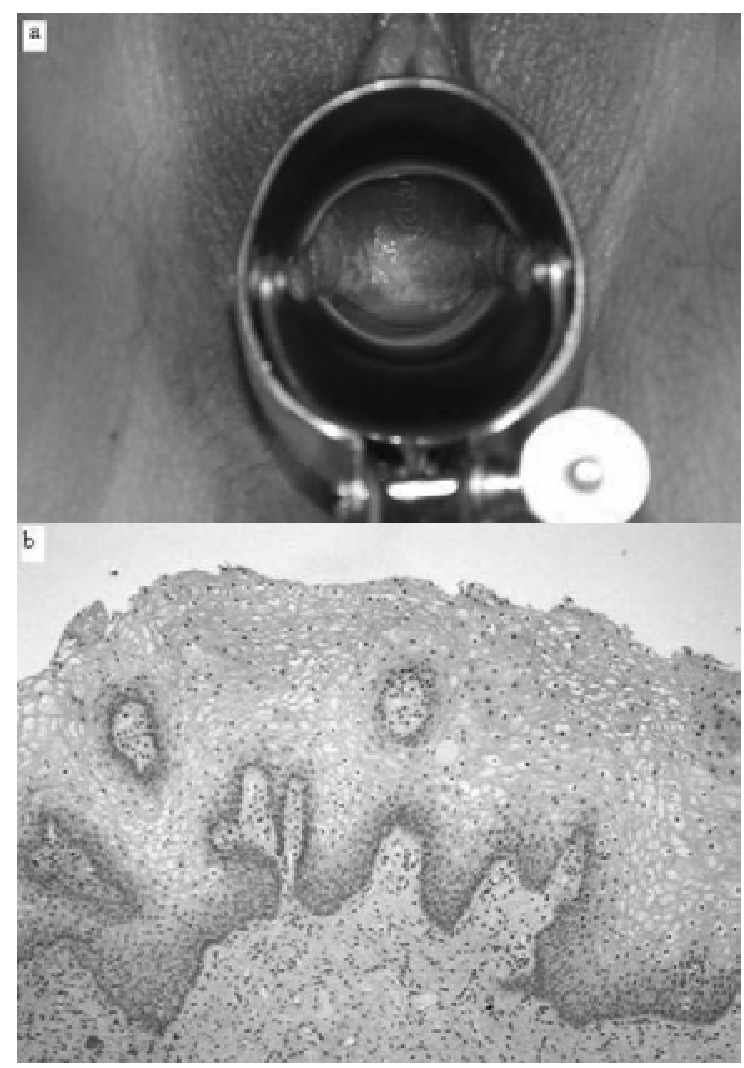

Figure 4: $a$. The 6th month speculum examination. b. Vaginal Epithelialization.
Two of our patients were married and when the patients and their husbands were asked about the satisfaction of sexual intercourse they mentioned they were happy with the results. One patient did not have any intercourse six months after operation.

\section{DISCUSSION}

MHRK syndrome consists of agenetic uterus, cervix and upper $2 / 3$ part of the vagina. On the other hand these patients have normal phenotype, endocrinologic profile, outer genitalia. Therefore the will of both the patients themselves and partners, to have normal sexual life, is the most important point of the treatment. The procedure performed to supply this will is expected to create anatomically and functionally the closest vagina to normal, estimated stricture ratio should be minimal, operative morbidity should be minimal, results should be cosmetically good both in the genital area and the others sites of the body; these are the expected results of this procedure ${ }^{(10)}$. In order to achieve these results lots of operation are defined in years.

Creating a new vagina using dilators increasing diameter and length dilator was described by Frank in 1938(11). Although accomplished results are announced about this technique, anxiety, lack of compliance, discomfortablity is mentioned as disadvantages ${ }^{(12)}$.

McIndoe (Abbe-McIndoe-Reed) technique is one of the most mentioned procedures in medical literature. The technic is the creation of a new vagina by a dilator which is wrapped by partial thickened skin grefts from hip, thigh or abdomen, is applied for seven days to the space made after the blunt dissection of the cavity between rectum and bladder. The greft becomes epithelialized during the following period and covers the new forming vagina. Low morbidity and having no need to abdominal approach can be mentioned as advantages but also have disadvantages as worse cosmetic results at greft space, need of dilator usage after operation, stenosis in new vagina, need of lubricant use in intercourse ${ }^{(6,13)}$.

Intestinal vaginoplasty is a technique that new vagina is created by using rectum, sigmoid coloumn or part of ileum. The 10-12 cm intestinal part which is liberalized, is transposed to the pelvis while the vascular pedincule is protected, and the proximal end in the abdomen is closed. After the segment is removed, the 
rest part of intestine is anastomosed endways ${ }^{(3)}$. Advantages are no need of dilation after operation, early intercourse, no need of lubricant usage, by the way disadvantages are difficult surgical technique, high morbidity, having dense mucoid vaginal discharce after operation, risk of prolapse and relative high risk of neoplasia $(3,15)$. Therefore it is suggested to be applied to patients whom have previous ineffective operations, instead of using as first-line treatment $(10,15)$.

Davydov procedure is composed of opening rektovaginal space perineally, then freeing the peritoneum from pelvik side walls and Douglas space abdominally and delivering the peritoneum to perinea. As can be seen the newly created vaginal surface is covered by peritoneum. The abdominal part of the procedure can be done laparoscopically nowadays. The main advantage is low morbidity and the disadvantages are post operative pelvik adhesions, post operative dilator requirement, operative difficulties when pelvik renal abnormalities present $(7,16)$.

Vecchietti technique is based on traction of the vaginal apex with strings entering from abdomen instead of using dilators to create neovagina. At the begining the combined usage of abdominal and vaginal ways is described but nowadays the blind vaginal apex is tracted laparoscopically using special devices and without opening rectovaginal space vaginally. Previously, there was no consensus about the traction devices, various surgeons used their own methods. Report states that using 'Neovagina Set' which is developped, standardized and certificated for this operation, the operation duration becomes shorter with lesser morbidity in comparison with older non-standardized traction devices ${ }^{(5)}$. Neverthless the placement of the newly developed traction device on the abdomen of the patients is controversial. Some authors prefer suprapubic installation, the others prefer umblical installation like us so the agenetic vagina is strecthed consistantly with the normal vaginal axis ${ }^{(5-7)}$. Generally, the advantages of the laparoscopical Vecchietti technique is short operation period, easy to learn, low morbidity, especially performable when pelvic renal abnormalities present, no need for lubricants during intercourse; the disadvantages are long hospitalisation period, long bladder catheterization period, post operative dilator requirement ${ }^{(5-7)}$. Furthermore the cost of the Neovagina Set itself and the high cost of long hospitalisation periods due to operative techiques are other disadvantages.
The surgical procedures discussed above have similar success and sexual satisfaction success rates but especially 'Modified Davydov and Modified Vecchietti' techiques draw the attention with lesser complications and can be performed laparospy. Modified Vecchietti operation is thought to be a step ahead because the operation doesn't involve vaginal interventions and the procedure can be applicated easily. Although the number of patients is limited to 3 in our report, the anatomical and functional vaginal length measurements are enough, 2 of the patients are satisfied with the sexual experience and the applicability of the operation is easy. Consequently treatment choices should be discussed with patients having MHRK Syndrome and the surgeon's experience about the procedure should be taken in consideration.

\section{Thanks}

Thanks to Dr. Sara Brucker for sharing technical information and experiences about laparoscopic assisted creation of neovagina using Neovagina Set.

\section{REFERENCES}

1. Rock JA, Aziz R. Genital anomalies in chilhood. Clin Obstet Gynecol 1987 Sep;30(3):682-96.

2. Oppelt P, Renner SP, Kellemann A, Brucker S, Hauser GA, Ludwig KS, et al. Clinical aspects of Mayer-RokitanskyKüster_Hauser syndrome: recommendations for clinical diagnosis and staging. Hum Reprod 2006 Mar;21(3):792-7.

3. Karateke A, Haliloğlu B, Parlak O, Cam C, Coskuer H. Intestinal vaginoplasty: seven years experience of a tertiary center. Fertil Steril. 2010 Nov;94(6):2312-5.

4. Alpaslan Kaban, Uğur Ateş, Işık Kaban, Alim Özcan. MayerRokitasky-Küstner-Hauser Sendromlu 35 yaşındaki hastanın siklik pelvik ağrı tedavisi. J Turk Soc Obstet Gynecol. 2012; 9(1):6-9.

5. Brucker SY, Gegusch M, Zubke W, Rall K, Gauwerky JF, Wallwiener D. Neovagina creation in vaginal agenesis: development of a new laparoscopic Vecchietti-based procedure and optimized instruments in a prospective comparative interventional study in 101 patients. Fertil Steril. 2008 Nov; 90(5):1940-52.

6. Fedele L, Frontino G, Motta F, Restelli E, Candiani M. Creation of a neovagina in Rokitansky patients with a pelvic kidney: comparison of long-term results of the modified Vecchietti and McIndoe techniques. Fertil Steril. 2010 Mar 
Fatih Sendag et al.

1;93(4):1280-5.

7. Bianchi S, Frontino G, Ciappina N, Restelli E, Fedele L. Creation of a neovagina in Rokitansky syndrome: comparison between two laparoscopic techniques. Fertil Steril. 2011 Mar 1;95(3):1098-100.

8. Walch K, Kowarik E, Leithner K, Schätz T, Dörfler D, Wenzl R. Functional and anatomic results after creation of a neovagina according to Wharton-Sheares-George in patients with MayerRokitansky-Küster-Hauser syndrome-long-term follow-up. Fertil Steril. 2011 Aug;96(2):492-7.

9. Vecchietti G. [Creation of an artificial vagina in RokitanskyKuster- Hauser syndrome]. Attual Ostet Ginecol 1965 MarApr;11(2):131- 47.

10. Davies MC, Creighton SM. Vaginoplasty. Curr Opin Urol. 2007 Nov; 17(6):415-8.

11. Ismail-Pratt IS, Bikoo M, Liao LM, Conway GS, Creighton SM. Normalization of the vagina by dilator treatment alone in Complete Androgen Insensitivity Syndrome and MayerRokitansky-Kuster-Hauser Syndrome. Hum Reprod. 2007 Jul;22(7):2020-4.
12. Liao L, Doyle J, Crouch NS, Creighton SM. Dilation as treatment for vaginal agenesis and hypoplasia: a pilot exploration of benefits and barriers as perceived by patients. J Obstet Gynaecol. 2006 Feb;26(2):144-8.

13. Klingele CJ, Gebhart JB, Croak AJ, DiMarco CS, Lesnick TG, Lee RA. McIndoe procedure for vaginal agenesis: longterm outcome and effect on quality of life. Am J Obstet Gynecol. 2003 Dec;189(6):1569-72.

14. Panici PB, Bellati F, Boni T, Francescangeli F, Frati L, Marchese C. Vaginoplasty using autologous in vitro cultured vaginal tissue in a patient with Mayer-von-Rokitansky-KusterHauser syndrome. Hum Reprod. 2007 Jul;22(7):2025-8.

15. Hensle TW, Shabsigh A, Shabsigh R, Reiley EA, MeyerBahlburg HF. Sexual function following bowel vaginoplasty. J Urol. 2006 Jun;175(6):2283-6.

16. Giannesi A, Marchiole P, Benchaib M, Chevret-Measson M, Mathevet P, Dargent D. Sexuality after laparoscopic Davydov in patients affected by congenital complete vaginal agenesis associated with uterine agenesis or hypoplasia. Hum Reprod. 2005 Oct;20(10):2954-7. 